\title{
Pajelança nas adjacências do Rio Amazonas: dimensões sociopolíticas e cosmológicas
}

\section{Pajelança 'shamanism' in the Amazon River adjacencies: sociopolitical and cosmological dimensions}

\author{
Leandro Mahalem de Lima 11
}

Resumo: Este ensaio etnográfico e comparativo aborda dimensões sociopolíticas e cosmológicas da "pajelança" entre as populações ribeirinhas - indígenas e caboclas - que habitam a zona de confluência entre os rios Tapajós, Arapiuns e Amazonas, em Santarém (centro-oeste do Pará). Baseado primariamente em diálogos e narrativas a que tive acesso durante pesquisas de campo realizadas entre 2008 e 2015, dialogo com estudos indígenas e rurais, clássicos e contemporâneos, exploro questões como: o que existe, como funciona e que sentidos tem um mundo que pressupõe a existência de sacacas e encantados? Quais as especificidades e efeitos sobre pessoas e coletivos, das ações rituais praticadas pelos sacacas? Por que e como a cultura dos sacacas é simultaneamente indígena e sincrética? O sincretismo pode ser entendido como modo de relação indígena, porque opera como estratégia de controle de poderes "de fora", que remete diretamente ao tema da abertura nas filosofias ameríndias. Não se trata de obliterar a importância da "mestiçagem" nas adjacências do rio Amazonas, mas de reconhecer as capacidades indígenas de incorporar pessoas, saberes e fazeres ao seu próprio estilo de civilização aberta, plural e não-centralizada.

Palavras-chave: Corpo e pessoa, xamanismo, indígenas e caboclos, Baixo Tapajós Amazônia brasileira.

\begin{abstract}
This ethnographic and comparative study explores sociopolitical and cosmological dimensions of pajelança (shamanism) as practiced among riverine peoples - Indigenous and Caboclos - in the zone of confluence between the Tapajós, Arapiuns and Amazonas rivers, in Santarém (midwestern Pará). It is primarily based on dialogues and narratives I accessed during fieldwork between 2008-2015; from which I dialogue with indigenous and rural studies, to address issues as: what exists in a world that presupposes existence of sacacas 'shamans' and encantados 'enchanted beings'? How does this world works and what (contradictory) meanings does it hold for those who share this world? What are the specificities and effects on persons and collectives, of ritual actions practiced by the sacacas? Why and how the culture of the sacacas may be simultaneously understood as indigenous and syncretic? In general terms, I propose that syncretism can be understood as a mode of indigenous relation, because it operates as a strategy to control dangerous and ambivalent powers "from the outside", leading to the theme of openness in Amerindian philosophies. It is not a matter of obliterating the importance of mestizaje, but of recognizing the indigenous capacities to incorporate new people, knowledge and practices into their own open, pluralistic, non-centered civilization.
\end{abstract}

\footnotetext{
${ }^{1}$ Doutor em Antropologia Social (USP). Pesquisador-associado ao Centro de Estudos Ameríndios (CEstA) da Universidade de São Paulo. Contato: Imahaleml@gmail.com
} 
Keywords: body, person, shamanism, Amerindians, Caboclos; Lower Tapajós, Brazilian Amazon.

\section{Introdução}

Apresento aqui uma descrição analítica sobre a pajelança, modalidade de xamanismo praticada entre populações ribeirinhas - indígenas e caboclas - na zona de confluência entre os rios Tapajós, Arapiuns e Amazonas, no município de Santarém e adjacências (centro-oeste do Pará). Para (re)introduzir a região e seus ocupantes, e (re)dimensionar ao leitor a relevância antropológica e política contemporânea do tema, faço uma breve recapitulação da longa história indígena nesta região de milenar ocupação e encontro entre povos falantes de línguas Tupi, Carib e Aruak. Conforme apontam estudos arqueológicos, a ocupação pré-colombiana na região, por pequenos grupos caçadores-coletores, recua mais de 10 mil anos antes do presente. Há pelo menos 1300 anos, as beiras de rios e os centros de mata já eram densamente ocupados por agricultores ceramistas integrados em extensas redes intercomunitárias ${ }^{2}$, Jamais foram extintos com o acaso da colonização.

A cronologia pós-contato abrange diferentes fases históricas ao longo de quatro séculos e meio, e se confunde com a própria história do Brasil nesta região da Amazônia. Primeiro, as expedições de reconhecimento e apresamento de escravos (1542-1616). Depois, o chamado período das missões (1616-1755), quando os jesuítas fundaram aldeamentos, nomeados em alusão aos gentios locais, onde estimulavam a conversão cristã e a comunicação em Língua Geral Amazônica (ou Nheengatú), de base Tupi. Na metade do século XVIII, os aldeamentos foram reclassificados em vilas e arraiais com nomes portugueses, ao passo em que os gentios passaram à categoria de índios cristãos ou civilizados; também chamados de tapuios ou caboclos. A língua portuguesa passou a ser obrigatória na comunicação entre os tuxauas ou capitães locais e os lusitanos. No sistema colonial, as categorias raciais estruturavam rigidamente as posições socioeconômicas. Os tapuios, puros ou misturados, formavam com os negros escravos, as castas servis, ditos "homens de cor"; enquanto os "brancos", auto identificados "homens de bem", ocupavam posições de mando. Nas últimas décadas do XVIII, os lusitanos

\footnotetext{
${ }^{2}$ Para mais sobre a história e as periodizações precisas e atualizadas do pré-colombiano na região, leia Gomes (2017).
} 
começaram a instituir na região os chamados "corpos militares de trabalhadores", formados fundamentalmente por "tapuios, puros e misturados", capturados para trabalhar forçadamente para a Coroa ou particulares ${ }^{3}$.

Em 1757, o jesuíta João Daniel (1841:168-170) - expulso da missão Arapiyú (Vila Franca) com a reforma pombalina - produziu o único relato etnográfico desta época sobre a "nação tapuia dos Arapiuns" e seus vizinhos Jaguaim e Gurupá, de Santo Inácio dos Tupinambás (Vila Boim). Entre outros "predicados dignos de nota", Daniel reportou a existência de figuras xamâmicas, descritas como "seus missionários", reconhecidos pela apresentação de "sinais de predestinação de cuja prova contam muitos casos" (:170). Destacou também que os Arapium, notadamente "seus missionários", tinham grande disposição para ouvir relatos sobre Cristo. Mas apesar da disposição a serem "bons cristãos", ainda praticavam rituais funerários nos quais o pó dos ossos do morto - parentes (endocanibalismo) ou inimigos (exocanibalismo) - era "misturado pelas velhas em vinhos" (fermentados alcóolicos) e bebido em "festas e beberronias" (:168)4. O jesuíta condenava estas e outras práticas "demoníacas" com açoitadas e outros castigos 5 .

Nos anos 1820 e 1830, as guerras de independência e as revoltas da Cabanagem sedimentaram na região pelo menos duas importantes mudanças sociopolíticas. Primeiro, a luta contra as estruturas servis do Antigo Regime, notadamente os corpos militares de trabalhadores, as torturas e proibições (da livre circulação à pajelança). Segundo, a construção de sentidos próprios e divergentes do pertencimento à nação dos brasileiros. A partir da metade do século XIX, a navegação internacional a vapor e o sistema de aviamento (escravidão por dívidas) impulsionaram a expansão da economia extrativista (seringa, juta, malva...), o pastoreio e a imigração de refugiados nordestinos. Naquele contexto, a categoria caboclo - historicamente utilizada como sinônimo de índio

\footnotetext{
${ }^{3}$ Para entrar na história dos tapuios e outros falantes de Nheengatú no vale do Amazonas, leia Bessa Freire (2004); Moreira Neto (1988).

${ }^{4}$ Outros costumes destacados: (i) os típicos festejos realizados precisamente no dia de aparição da lua nova, quando faziam rituais nos quais erguiam os braços em direção ao astro celeste pedindo força e saúde; (ii) rituais de iniciação femininos (realizados durante a menarca) e resguardos à circulação das mulheres fora de suas casas durante seus períodos menstruais; (iii) a semelhante ênfase aos rituais de iniciação masculina, nos quais os jovens tinham de suportar a dor de colocar os braços dentro de cabaças cheias de formigas tocandira (entre outras técnicas correlatas. Abordei o tema em meu doutorado (Mahalem de Lima, 2015)

${ }^{5}$ Para mais sobre a condenação à pajelança pelos jesuítas na região do Baixo Tapajós, leia, por exemplo, Vaz, 2010: 78.
} 
civilizado - passou a operar também como uma referência genérica ao modo de vida típico das comunidades rurais do vale do Amazonas e seus afluentes ${ }^{6}$.

No relato de sua expedição pelo rio Tapajós, Barbosa Rodrigues (1875), naturalista enviado pelo Imperador do Brasil, ainda se utilizava corriqueiramente dos termos "tapuios" e "índios" para designar os descendentes das "diversas tribos de gentios", que habitavam "povoações" ou "aldeias" formadas por "choupanas" ou "malocas", distribuídas pelo espaço das antigas vilas e missões do Baixo Tapajós (1875: 61). Em seu relato, os festins canibais - destacados por João Daniel um século antes e então abandonados abrem espaço às festas de Santo, como o "Çairé" na Alter do Chão, acompanhado de "cantos em Língua Geral" (id.:45) e regadas a uma "bebida espirituosa preparada com beijus de mandioca" que chamavam de "tarubá" (id.:43). Figuras xamânicas como os pajés não apareceram no relato do naturalista carioca muito provavelmente porque sua prática era ocultada pelos nativos, dado que considerada crime até (pelo menos) 19507.

Ainda na metade do século XX, o termo "caboclo" remetia à categoria dos índios, puros ou misturados, que habitavam comunidades ribeirinhas, distanciadas tanto do centros das vilas, associados aos brancos, quanto dos centros de mata, associados aos ditos índios puros e tribais ${ }^{8}$. Entre populações deste tipo, o Português falado é profundamente influenciado pela gramática, as expressões e os sistemas vocabulares do Nheengatú. Sua tradicional economia mista de subsistência constitui uma evidente atualização de técnicas indígenas de cultivo, pesca e caça? Assim como as formas elementares de sua religiosidade - e o regime sociocosmológico subjacente - são marcados pela existência de encantados e pajés sacacas, e a cultura das festas de santo.

Foi sobretudo a partir dos anos 1970, no contexto da chamada "Segunda Colonização da Amazônia”, promovida pela Ditadura Militar (1964-1985), que o termo "caboclo" se sedimentou na antropologia e no senso comum regional como uma referência à cultura mestiça e sincrética das comunidades rurais amazônicas. Para a sociologia do campe-

\footnotetext{
${ }^{6}$ Para entrar sobre a Cabanagem, a partir da antropologia, leia Harris (2010), Mahalem de Lima (2008, 2015).

${ }^{7}$ Para mais sobre a criminalização de práticas indígenas e afrodescendentes - como as pajelanças, feitiçarias e religiões afro-brasileiras na Amazônia entre 1870-1950, leia Moura de Figueredo (1996).

${ }^{8}$ Cf. Charles Wagley ([1953] 1957) e Eduardo Galvão (1955) sobre a região de Gurupá (a fictícia Itá), ou Betty Meegers (1950) sobre o Marajó.

${ }^{9}$ Para uma revisão dos usos da categoria social caboclo, Grenand \& Grenand (1990); Lima (1992).
} 
sinato, era fundamental evidenciar que, por baixo do "vazio populacional" da Amazônia, havia "índios tribais", mas também "comunidades rurais tradicionais", as "sociedades caboclas", igualmente ameaçadas pela rápida expansão dos novos assentamentos e grandes projetos de desenvolvimento. Naquele contexto, se delinearam duas vertentes interpretativas sobre o estatuto sociológico das "sociedades caboclas". Uma propunha defini-las como uma espécie de "campesinato indígena", retomando o sentido clássico do termo, enquanto a outra argumentava que fazê-lo seria reduzir a heterogeneidade das comunidades rurais a apenas um de seus tipos formadores ${ }^{10}$

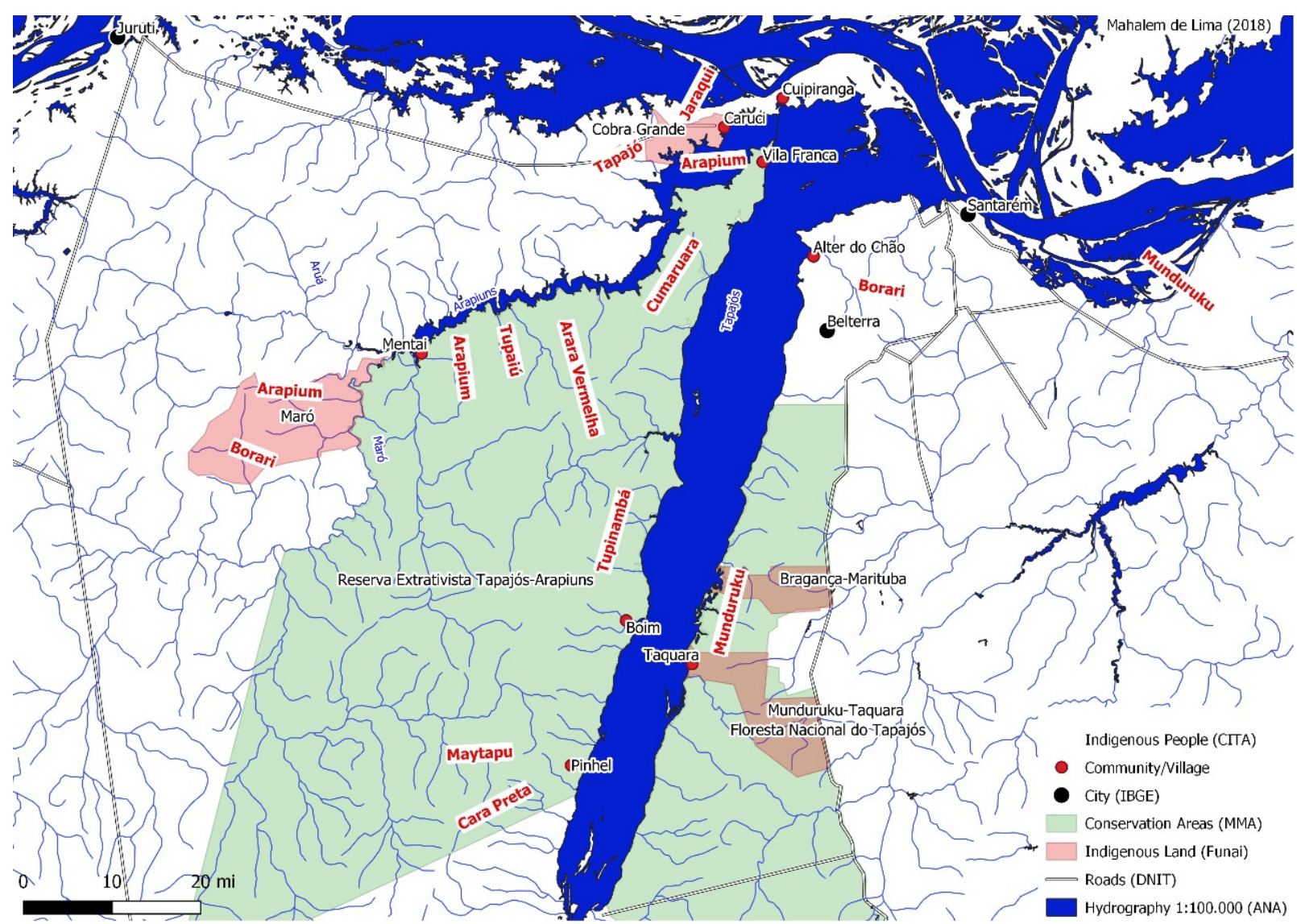

Figura 1. Mapa da zona de confluência entre os rios Tapajós, Arapiuns e Amazonas, com principais Áreas Protegidas (Tis, Resex, Flona) e povos indígenas contemporâneos.

Desde o fim dos anos 1980, os direitos fundamentais garantidos aos povos indígenas e outras categorias de populações tradicionais, na chamada "Constituição Cidadã" (1988), impulsionaram um novo ciclo histórico nesta e outras regiões do país. Atualmente, existem diversas modalidades fundiárias destinadas ao usufruto coletivo exclu-

\footnotetext{
${ }^{10}$ Sobre a ideia de "Segunda Colonização da Amazônia" leia Maybury-Lewis (1983), Parker (1985) ou Nugent (1993).
} 
sivo por indígenas e tradicionais, que justapõem-se ou sobrepõem-se umas às outras. As primeiras áreas protegidas em debate na região, nos idos da Eco-1992, foram as unidades de conservação ou os assentamentos rurais de uso sustentável, destinados a "populações tradicionais'11. Em 1996, universitários nascidos em comunidades ribeirinhas, residentes em Santarém, envolvidos nestes processos, passaram a assumir para si identidades indígenas e fundaram uma organização não-governamental - o Grupo de Consciência Indígena (GCI) - para disseminar suas ideias. O Conselho Indígena Tapajós Arapiuns (CITA) - associação interaldeã fundada em 2000, "filha do GCl" - estima que existem atualmente (2015) na região, cerca de 6000 pessoas, na cidade de Santarém e em outras 67 localidades (aldeias, comunidades, vilas) que pertencem a 13 povos ou etnias indígenas ${ }^{12}$.

Em um primeiro momento, a assunção de identidades culturais divergentes - indígena ou cabocla, indígena ou tradicional, indígena ou branca - com efeitos sobre 0 acesso a direitos de usufruto coletivo, geraram relativa tensão e incerteza. Contudo, cada vez mais as diversas modalidades de usufruto coletivo tradicional e seus proponentes tendem a caminhar rumo a soluções locais negociadas, que reafirmam o caráter complementar e não excludente de modalidades alternativas. Afinal, a despeito das diferenças, e de um ponto de vista jurídico, indígenas, caboclos e quilombolas se equiparam enquanto "populações tradicionais", protegidas por instrumentos do direito interno e internacional, como a Convenção no 169 da Organização Mundial do Trabalhd ${ }^{13}$.

Em antropologia, o contexto contemporâneo de reflexividade e afirmação de identidades culturais, implica também o trabalho de reposicionar e atualizar descrições e modelos sedimentados. Para o frei e antropólogo maytapu Florêncio Vaz (2010), eminente líder e fundador do $\mathrm{GCl}$, os três principais aspectos histórico-culturais que justificam e dão sentido às etnogêneses em curso na região são: a Cabanagem (já mencionada), as

\footnotetext{
${ }^{11}$ A primeira Reserva Extrativista do Brasil, Alto Juruá, foi criada por inspiração da "Aliança dos Povos da Floresta". Envolveu figuras como Chico Mendes e resultou também na criação Conselho Nacional dos Seringueiros (CNS). Para mais, cf. Almeida (2001). Na região em questão, principais áreas de uso sustentável são a Reserva Extrativista Tapajós Arapiuns (1998), o Assentamento Agroextrativista da Gleba Lago Grande do Curuaí (2005) e a Floresta Nacional do Tapajó (1974). Para mais, leia Vaz Filho (2010), Bolaños (2010), Stoll (2014) ou De Lima (2015).

${ }^{12}$ Cf. Vaz Filho, Tapajós, Cardoso (2017) para um balanço atualizado da situação indígena na região, feito por antropólogos indígenas.

${ }^{13}$ Para mais sobre complementaridade entre direitos coletivos no âmbito da Convenção OIT n. 169, veja De Lima (2017).
} 
Festas de Santo ${ }^{14}$ (também mencionadas) e a Pajelança (foco deste artigo). Para Vaz, atualizar o lugar dos indígenas na história é reposicionar a "pajelança cabocla" como uma expressão cultural "indígena". Implica problematizar estudos clássicos como os de Wagley (1953) e Galvão (1955), ou de Heraldo Maués (1977) - célebre antropólogo paraense, que interpretou a "pajelança cabocla" como prática cultural sincrética associada à mestiçagem racial na Amazônia rural.

O mundo dos sacacas e encantados tem importância destacada para os antropólogos e conhecedores tradicionais indígenas ${ }^{15}$, Nas narrativas sobre a gênese do movimento indígena regional dois falecidos pajés sacacas ocupam uma posição especial. Um deles é Laurelino, interlocutor privilegiado de Vaz em suas pesquisas de campo em Takuara (Baixo Tapajós), que se definia como um "descendente de índios", simpático ao reconhecimento indígena. Foi em 1998, após sua morte, que seus próprios descendentes decidiram se assumir como indígenas Munduruku, dando início a processos semelhantes e conexos em toda região. O outro pajé sacaca destacado nas narrativas é Merandolinq ${ }^{16}$, mestre de Laurelino no Alto Arapiuns. Ele é descrito como um homem que voluntariamente se tornou um encantado e se veste de Cobra Grande para circular entre o encante no fundo e a terra. Ele também ocupa a posição de dono (ou mãe) dos peixes e do rio Arapiuns. Foi este emblemático sacaca que serviu de mote para a eleição do nome Cobra Grande, para a Terra Indígena reivindicada conjuntamente pelos Arapium, Tapajó e Jaraqui no Baixo Arapiuns.

Mas o que existe, como funciona e que sentidos tem um mundo que pressupõe a existência de sacacas? Quais as especificidades e efeitos sobre pessoas e coletivos, das ações rituais praticadas pelos sacacas? Por que e como a cultura dos sacacas é simultaneamente indígena e sincrética?

Este relato etnográfico e comparativo sobre a pajelança tem por base observações participantes que realizei em cinco etapas entre 2008 e 2015, que explorei em minha tese de doutorado (2015) e outros estudos. Trabalhei sobretudo na supracitada

\footnotetext{
${ }^{14}$ Além dos trabalhos de Vaz Filho (2010), leia também Stoll (2015) sobre a "Farsa dos Pretos" prática ritual encenada durante as festas de santo dos Tapajó (comum entre indígenas e tradicionais); e Vaz (2010) sobre a dança do Gambá de Pinhél e outros festejos como o Marambiré do quilombo de Pacoval.

${ }^{15}$ Entre outros materiais, veja as coletâneas de narrativas sobre os encantados e pajelança, organizadas por Vaz Filho (2013), Vaz Filho e Cardoso (2016).

${ }^{16} \mathrm{Cf}$. Mahalem de Lima (2015) e Stoll (2016) para mais sobre Merandolino.
} 
Terra Indígena Cobra Grande, e circulei também em outras aldeias Arapium, Tupaiú, Borari, Tupinambá, Munduruku e Maytapu. Conheci um quilombo no rio Curuá e convivi com populações tradicionais "caboclas"; notadamente segmentos residenciais com nexos de parentesco e coresidência com os indígenas, nas áreas protegidas de uso sustentável (Resex, PAE, Flona). Em interlocuções aprofundadas e no cotidiano, pude confirmar a notável relevância que figuras como os sacacas e os feiticeiros têm na vida de pessoas comuns (não sacacas), de diferentes perfis - homens e mulheres, velhos e jovens, católicos e protestantes, indígenas e caboclos. Fiz entrevistas e convivi (em maior ou menor medida) com quatro "curadores"; dois homens e duas mulheres: (i) uma anciã entre os Arapium de Nova Vista (Alto Arapiuns); (ii) uma mulher adulta entre os Jaraqui em Lago da Praia (Baixo Arapiuns); (iii) um homem adulto, Arapium de São Pedro (Alto Arapiuns), na periferia de Alter do Chão; (iv) um ancião não-indígena entre os Arapium do Caruci (Baixo Arapiuns).

Na sequência, desdobro temas e problemas em uma série de tópicos interconectados. Trata-se de uma descrição sintética de pontos chave, com base nos diversos diálogos e narrativas a que tive acesso. A premissa subjacente a este exercício - formulada com base em Seeger, Da Matta \& Viveiros de Castro (1979) - é que, na Amazônia indígena, a noção de pessoa e a corporalidade operam como idiomas focais e informam a práxis concreta de um modo próprio e claramente reconhecível. Discuto, neste sentido, possibilidades de repensar as evidentes continuidades culturais entre povos indígenas e camponeses tradicionais nas adjacências do rio Amazonas.

Primeiro falo sobre os patamares fundamentais de seu mundo habitado (a terra, o céu e o fundo) e sobre as especificidades da pessoa humana (a capa, a sombra, o espírito, a fala...). Em seguida, abordo os atributos distintivos do sacaca (seu corpo, seus artefatos e técnicas), e também sentidos associados às diferentes categorias nativas de xamãs (sacaca, pajé, curador, feiticeiro, macumbeiro...). Focalizo então, as especificidades e diferenças entre as agressões virtuais provocadas pelos humanos (judiaria, malefício e puçanga), e pelos encantados (mau olhado, assombro, flechada, roubo). Chamo atenção para a centralidades das dinâmicas relacionais triangulares ou triádicas, que envolvem humanos e encantados entre a terra e o fundo. Saliento então as diferenças entre transformações corporais praticadas por sacacas e encantados, e as metamorfo- 
ses vividas por tipos como os homicidas e outros pecadores. Esboço então controvérsias e diferenças de interpretação sobre as relações entre a pajelança, a parte de deus e a parte do inimigo. Para finalizar, retomo a discussão sobre as continuidades e descontinuidades entre os modelos culturais indígena e caboclo.

\section{Na terra, entre o céu e o fundo}

Em geral, as pessoas postulam que no mundo existem três planos habitados: 0 céu, a terra e o fundd ${ }^{17}$. O céu é o domínio de deus, dos santos católicos, dos espíritos bons. O fundo é o lugar onde moram as "mães ou donos" de todos os bichos e paragens que existem na água, na terra e no $a r^{18}$. "É um encante, uma cidade encantada". Lá moram não só mães ou donos, mas também diferentes "bichos", "gentes", "parceiros" ou "caboclos", capazes de aparecer em terra na forma de qualquer vivente $e^{19}$.

A terra, onde "gente como a gente" vive, é o plano intermediário entre o céu e o fundo. No espaço geográfico, casas e colônias de produção se distribuem entre a beira dos rios e lagos e os centros de mata. As beiradas e a jusante do rio são comumente associadas à civilização, enquanto que a montante do rio e os centros de matas são associados à braveza e à selvageria. Não raro, o fundo, ou o encante, é entendido e descrito como um domínio fundamentalmente subaquático, cujos habitantes são colocados em oposição aos bichos de terra perigosos, que habitam os centros de mata.

\section{A "formatura do bicho homem falado" e os "dons do sacaca"}

Os curadores com quem dialoguei, bem como outros informantes de diferentes gêneros e idades, apresentaram um amplo consenso com relação aos componentes

\footnotetext{
${ }^{17}$ Já dito, e retomaremos, o que observei ressoa a Eduardo Galvão (1955) e diversas etnografias posteriores no vale do Amazonas e principais afluentes Leia, por exemplo, C. Slater (1994) sobre a região de Parintins (Amazonas); H. Maués (2003, 2005) sobre zona Bragantina (Vigia, Pará); Mark Harris (2000, 2003) e Mark Cravalho (1999) no baixo rio Paru (Óbidos, Pará); Marta Amoroso (2012) sobre os Mura do médio rio Madeira (Amazonas); Florêncio Vaz (2010), Edviges loris (2011), João Valentin Wawziniak (2012), Emilie Stoll (2015) no baixo rio Tapajós e Arapiuns (Santarém, Pará).

${ }^{18}$ O tema das "mães ou donos" já destacado por Wagley \& Galvão nos anos 1950, como legados da tradição Tupi, tornou-se nas últimas décadas um tema chave na etnologia ameríndia por sua ampla disseminação e variação entre os mais diversos povos indígenas (e.g. Viveiros de Castro, 2002; Fausto, 2008). Nos termos de Carlos Fausto, estas categorias transcendem uma simples relação de propriedade ou domínio, pois que designam "um modo generalizado de relação, que caracteriza as interações entre humanos, entre não-humanos, entre humanos e não-humanos e entre pessoas e coisas" (2008: 329).

${ }^{19} \mathrm{O}$ "céu" ocupa lugar homólogo ao "fundo" entre muitos povos indígenas na Amazônia. Para mais, leia a etnografia de F. Maizza (2012) sobre "o mundo perigoso" dos Jarawara.
} 
materiais e imateriais elementares que constituem a pessoa humana: a capa ou a vestimenta, a sombra, o espírito, o sangue e a capacidade de falar, pensar e sentir.

"A capa é só a formatura do bicho homem falado", sintetizou-me a curadora arapium em Nova Vista. Durante a gestação, todo nascituro passa a dispor de uma "capa", habitada pelo "espírito" e a "sombra", componentes imateriais da pessoa: "é a vida da gente; tirou, pronto", reiterou a anciã. Embora sejam categorias próximas, tomadas comumente por intercambiáveis em diversos contextos, os conhecedores mais renomados reiteraram que espírito e sombra designam componentes distintos da pessoa. Dizem que o espírito pertence a deus e tem como destino pós-morte ideal o céu, enquanto que a sombra pertence aos encantados e tem como destino o fundo - sobretudo se for sacaca. Reitera-se comumente também que aquele que "morre sem esperar", como o enforcado, o afogado ou o atirado, fica vagando por terra e passa à categoria dos espectros que chamam de "visagens".

A principal característica do sangue é o seu cheiro forte ("pitiú"), agradável e atrativo para os bichos que habitam a mata e o fundo. A cognição e a volição -ou a concatenação e expressão de pensamentos e vontades em fala - assim como os afetos, são as qualidades básicas da "verdadeira pessoa", "para o bem ou para o mal". Comumente, capacidades como cognição e volição são evidenciados em fala pela negativa. Os temas comuns do "endoidar" e do "amortecer", ou desfalecer, caracterizam a perda destas capacidades. Estas duas categorias remetem à dualidade entre os transes catapléticos e dramáticos, debatidos por psicólogos e antropólogos em diferentes contextos etnográficos 20 . A pessoa "endoida" ou "amortece" quando tem sua "sombra roubada" por um encantado ou quando é enfeitiçada; situações em que a pessoa se distancia da posição de "gente" e passa ao campo dos outros: bichos, encantados, bravos, inimigos.

Os sacacas são diferentes das pessoas comuns porque recebem "de nascença" seus dons - característica que ecoa à supracitada predestinação dos missionários arapium, há muito descrita pelo jesuíta João Daniel [1757]. Além de fazerem proezas como chorar no ventre da mãe, são gestados em uma "capa" diferente; isto é, uma placenta diferente daquela que envolve a pessoa comum. Em tenra idade, já se mostram capa-

${ }^{20}$ Cf. Chaumeil ([1982] 1998:138) para as bases do debate sobre a Amazônia indígena. 
zes de conversar com pessoas invisíveis, e com frequência perdem momentaneamente a consciência ("endoidam" ou "amortecem").

Todas as crianças nascem com o "corpo aberto", mas aqueles que carregam o dom da cura têm esta característica mais exacerbada. Caso não cuidem de sua abertura, podem, com maior facilidade que os comuns, ter sua sombra roubada ou flechada pelos encantados. Os ataques de bichos do fundo (que retomaremos) Ihe acarreta uma vida de tormentos que pode levar à captura ou mudança voluntária em definitivo para o encante, para junto de sua gente por lá. A mudança voluntária é o caso do sacaca Merandolino, mencionado na introdução.

Como também mencionado, o destino post-mortem do sacaca é diferente da pessoa comum. Para os comuns, apesar do destino desejado ser o céu, junto a deus, em sombra e espírito, há sempre a possibilidade do roubo ou da atração para o fundo pelos encantados. Ou então a chance de passar para o inferno, junto àquele que chamam de "inimigo". "O sacaca é diferente porque é dividido", destacaram os pajés com quem dialoguei. Seu destino ideal é duplo: a sombra para os encantados e o espírito para deus.

Não raro, curadores e pessoas comuns ressaltaram que os sacacas são parte de linhagens que vivem entre o fundo e a terra. Homens e mulheres podem transmitir seus dons para seus filhos e netos. Significa que um velho sacaca já morto tem relação com um bebê que apresenta o dom. E também que uma "gente" ou "parentagem" no fundo transmite suas habilidades aos seus em terra, desde tempos imemoriais. Embora existam famílias de sacacas fortes, não me parece que chegam a constituir linhagens especializadas, distintas das linhas de filiação formadas por pessoas comuns. É provável que toda pessoa tenha em suas memórias genealógicas algum ancestral, mais ou menos próximo, se não adotivo, com habilidades de sacaca. E por consequência, toda gestação é o gérmen potencial de uma pessoa que carrega o dom. Neste sentido, os sacacas do Arapiuns parecem se aproximar mais dos tipos que Stephen Hugh-Jones chamou de "xamãs horizontais" - com especialidades derivadas da inspiração e do carisma; e com atuação voltada para o exterior, marcada pela ambivalência moral entre a cura e a agressão. E menos com os "xamãs verticais", voltados à reprodução das relações 
internas do grupo, com especialização de tipo pacífico, hierárquico e sacerdotal - como os kumu entre os Tukano no Rio Negro ${ }^{21}$.

Dado que encantados, os sacacas também têm a habilidade de vestir e desvestir diferentes capas corporais para transitar entre o fundo e a terra. No Português falado, o vestir e desvestir capas corporais remete a expressões como "se gerar", "se transformar", "se transpassar" ou "adquirir uma formatura". Apesar da capa de cobra grande ser a mais comumente destacada nas narrativas, ela não é a única, pois que qualquer encantado pode vestir qualquer capa de qualquer ser vivente. Deste modo, sacacas e encantados circulam pelos mesmos caminhos entre a terra e o fundo, em direções opostas.

É durante estas viagens ao fundo que aprendem rezas e usos de remédios da mata (ou da farmácia) que irão utilizar na cura dos enfermos. Além de viajar para o fundo, os sacacas são capazes de permitir que seus corpos sejam utilizados por "sua gente", seus "parceiros do fundo", para que eles próprios possam se comunicar com as pessoas comuns, fornecendo o diagnóstico e a cura para patologias que acometem as pessoas. Neste momento ritual, sacacas e encantados trocam de posições. Enquanto os encantados ocupam a capa corporal do sacaca, o espírito deste se veste com uma outra capa e circula pelo fundo, até novamente retornar à sua própria, sem nada saber sobre o que se passou por ali. Uma suposta diferença elementar entre estes dois processos encontra-se na base de distinções tipológicas entre a pajelança cabocla, associada aos rituais de possessão, e o xamanismo indígena, associado à viagem cósmice22. Contudo, na Amazônia indígena não há contradição, mas complementaridade entre estas operações do espírito, como demonstrou pioneiramente Jean-Pierre Chaumeil (1998 [1983]), a partir dos Yagua (Amazônia peruana).

O dom "de nascença" é descrito como um fardo: o sacaca tem o dever de se dedicar à cura. Este fardo remete a um sistema de pensamento que estabelece que na base de todos infortúnios que se abatem sobre os corpos, existe um potencial agente responsável, humano ou encantado. Estes infortúnios estão associados a represálias e a

\footnotetext{
${ }^{21} \mathrm{Cf}$. S. Hugh-Jones (1994) para a distinção entre xamanismo vertical e horizontal em um panorama comparado. Para desdobramentos cf. Viveiros de Castro (2002: 470) e Fausto (2008: 349).

${ }^{22}$ Sobre a distinção entre pajelança cabocla, associada à possessão, e o xamanismo indígena, associado à viagem cósmica, cf. Boyer, 1999; Maués, 1993; Maués \& Villacorta, 2008. Talvez o corte faça sentido para contrastar expressões xamânicas e rituais indígenas (e.g. o sacaca caboclo e o kumu tukano) e afro-brasileiras (e.g. Candomblé, a Umbamda, o Tambor de Mina).
} 
infrações de regras de boa convivência que exigem reparação; mas também ao agradarse e à sedução - como no caso típico de botos e sereias que atraem e estabelecem relações íntimas com homens e mulheres ${ }^{23}$. Abrangem as (i) agressões provocadas por outros humanos, as diferentes categorias nativas de feitiçaria; e as (ii) agressões provocadas pelos encantados do fundo; como o "roubo" e o "ataque de bicho" (mais adiante $e^{24}$.

Meus interlocutores comumente ressaltavam frases como: "já não existem sacacas como antigamente". Quem tem o dom no presente é por definição mais fraco do que aquele que existiu "de primeiro". Neste sentido, as categorias pajé e curador são comumente reservadas aos mais fracos e aos atuais, enquanto que o termo sacaca remete aos fortes e ao passado. No entanto, esta distinção em força nada têm de definitiva, uma vez que os curadores do presente se referem a si ou são qualificados por outros como verdadeiros sacacas, em diversos contextos de enunciação. Do mesmo modo, a pessoa que hoje se define como um "humilde curador", será para seus filhos e netos depois da morte, um "grande e verdadeiro sacaca". O caso do curador Laurelino - mencionado na introdução e retomado adiante - é uma típica atualização desta operação 25 .

Os sacacas são também descritos como o oposto dos feiticeiros. Estes últimos são aqueles que se voltam à agressão, "por intermédio do inimigo". Não raro as pessoas associam a feitiçaria ao aprendizado em livros, como o livro de São Cipriano, "santo que pertence à parte do inimigo". Mas assim como a distinção entre sacacas fortes do passado e pajés fracos do presente, a distinção entre sacacas e feiticeiros não é estanque. Afinal, tanto aquele que recebeu o dom de nascença, como aquele que aprendeu nos livros depois de velho, pode se voltar à cura ou à agressão. Por isso, um pajé ou curador sempre procurará ressaltar que tem reconhecidos dons de nascença e que suas habilidades se assemelham às dos antigos sacacas.

\footnotetext{
${ }^{23}$ Para interessantes estudos sobre a sedução do boto, leia Slater (1994) e Lima (2014).

${ }^{24}$ Estas categorias de agressão, amplamente disseminadas nas "áreas culturais caboclas", remetem a diversas etnografias sobre povos indígenas. Veja o estudo clássico de Chaumeil sobre o xamanismo Yagua (1998 [1983]), ou o caso Wajãpi (Gallois, 1988), com diversas semelhanças explícitas.

${ }^{25}$ Este contraste entre sacacas fortes do passado e pajés fracos do presente foi observado entre diversas populações do vale do Amazonas, baixo rio Tapajós e Arapiuns (Galvão, 1955; Slater, 1994; Wawziniak, 2008; Vaz, 2010; loris, 2011), também é um tema comum no xamanismo indígena (e.g. Chaumeil, 1983; Gallois, 1988).
} 
Não raro, os terreiros de umbanda ou candomblé são as representações típicas da prática heteróclita, potente e perigosa, que levanta curiosidade e suspeita. Os médiuns kardecistas também são lidos nesta chave. Para além dos jogos de boatos, suspeitas e acusações, há consenso de que há muito a aprender com qualquer tipo que tenha o dom, e trabalha com métodos diferentes do sacaca. Por isso as pessoas não só os procuram em lugares distantes, mas também os convidam às aldeias e comunidades para tentar solucionar problemas que ninguém "de dentro" ainda não conseguiu resolver. Contudo, esta é uma operação arriscada. Afinal, mesmo se o "macumbeiro" trouxer a cura almejada, sua presença pelas proximidades, dentro das comunidades ou aldeias, é ambivalente e perigosa; gera inevitáveis tensões e boatos entre vizinhos.

O artefato distintivo do sacaca é o cigarro enrolado em entrecascas da árvore do tauari, que envolvem, além do tabaco, outras "plantas fortes" como murasacaca, paricá, cipó-alho e envirataia. Rezar e soprar a fumaça destes cigarros sobre o corpo do enfermo, em rituais feitos com discrição, dentro de suas próprias casas, idealmente a boa distância dos espaços comunitários, é o básico do trabalho. Sobre aqueles que não usam estes métodos tradicionais recaem inevitáveis suspeitas. A habilidade no uso dos cigarros de tauari também lhes serve para enfatizar a força dos grandes sacacas de antigamente. Muitos contam que quando queriam, os sacacas acendiam seu cigarro, mergulhavam ao fundo, onde vestiam a capa de Cobra Grande, e saíam do outro lado do rio ainda com o cigarro aceso, algo impossível para os pajés e curadores do presente. Para muitos no Arapiuns, Merandolino foi o último sacaca com essa capacidade.

Um outro aspecto do trabalho ritual é o uso de cachaça para atrair e agradar "seus parceiros", "seus parentes", "sua gente" no fundo. Diz-se que os encantados, quando estão de posse do corpo de um verdadeiro sacaca, bebem apenas a "fortidão da cachaça", de modo que, ao fim dos trabalhos, o álcool no copo se torna água pura. Se o pretenso sacaca bebe o destilado durante os trabalhos, então suspeitas de feitiçaria e enganação poderão ser levantadas ou justificadas.

Estes trabalhos rituais, com cigarros de tauari e cachaça, nos quais os pajés sacacas chamam seus parceiros do fundo, são geralmente feitos diante de bancadas repletas de amuletos. Inadvertidamente, acima, sobre e envolta destes altares são colocados cru- 
cifixos, bíblias, terços e imagens de santos, entre velas brancas. Estas representações cristãs são fundamentais para marcar que o trabalho é feito "abaixo de deus, sem parte com o inimigo e a feitiçaria". Às imagens cristãs são associados diversos outros artefatos de valor simbólico para o curador, como penas de pássaros, com histórias e valores próprios, ligados aos parceiros no fundo. Para aqueles que os procuram em suas casas, artefatos como as velas pretas e vermelhas, ou mesmo livros que não sejam a bíblia, podem levantar suspeitas de práticas de feitiçaria e "parte com o inimigo".

Em geral, afirma-se que um verdadeiro sacaca não coloca preço em seus serviços, ao passo em que um feiticeiro ou enganador cobra caro e está interessado apenas em obter ganhos materiais das famílias dos enfermos. Assim, para ganhar dinheiro e atrair clientes cativos, pode ele mesmo "fazer a judiaria". Nunca se sabe e por isso depender de sacacas é perigoso, "a pessoa pode se tornar um servo". Uma vez que a atitude prudente é viver a certa distância e não precisar recorrer a pajés, é suspeito de feitiçaria também aquele ou aquela que visita com frequência estes especialistas em momentos de relativa calmaria.

\section{Variações das agressões causadas por gente ou encantado}

Conforme meus interlocutores, existem três tipos básicos de feitiçaria, ou agressão virtual causada por gente ou encantado: (i) a "judiaria", agressão que tem por objetivo judiar, torturar, provocar dores que podem ser remediadas; (ii) o "malefício", agressão que visa a morte; e (iii) a "puçanga" ou o "chama", para atrair, seduzir ou encantar, fazendo com que o agredido se torne um servo das intenções e desejos do agressor. Por exemplo, o "homem puçangueiro" que "atrai a mulher desejada"; ou o "cacique macumbeiro" que "mantém a comunidade aos seus pés e em silêncio".

Um elemento fundamental para a identificação de uma enfermidade como uma agressão de feitiçaria de origem humana é a presença de bichos patológicos que "se geram" no corpo do enfermo. Os "bichos feios gerados no corpo" são basicamente insetos, larvas, cobras ou tumores. Alguém pode procurar um curador por já ter identificado a presença destes bichos em seu corpo. Ou então, o próprio pajé pode extrair um ou vários agentes patogênicos durante sua ação ritual, não deixando dúvidas sobre a agressão feiticeira e a efetividade de seu trabalho. O curador bem-sucedido no combate à judiaria, 
"faz a pessoa virar gente de novo". Contudo, se o diagnóstico for de malefício, então é porque a doença já está "alcançada" e a morte é o destino inevitável. Daí a importância de levantar recursos, fazer o possível para ouvir o diagnóstico de outras categorias de curadores, complementarmente à busca por médicos. Em casos confirmados de agressão e identificação indubitável do agressor, o doente ou seus familiares próximos poderão solicitar um pajé para que ele faça "a volta"; isto é, que ele devolva à gente do agressor a agressão sofrida, em igual ou maior medida.

As agressões de feitiçaria e suas voltas constituem, portanto, um idioma fundamental por meio do qual as relações políticas de aliança e hostilidade intercomunitárias são expressadas e mobilizadas. As mútuas acusações de feitiçaria são como ciclos de agressões e vinganças que envolvem os diversos segmentos residenciais que habitam as comunidades ou aldeias. Ambos os lados envolvidos procuram o apoio e a proteção de pajés que, por sua vez, podem estabelecer entre si longas disputas intermediadas pela ação dos encantados, aliados de uns ou outros.

Nestas disputas cosmopolíticas ${ }^{26}$, é comum que cada parte trabalhe para amplificar suas forças por meio da busca do apoio de curadores reputados como fortes, em comunidades mais afastadas ou nas cidades; Santarém, Faro, Óbidos, Parintins, Manaus. Do mesmo modo, os "sacacas verdadeiros e de dentro" também circulam pelas cidades e outros lugares distantes, para incorporar saberes e fazeres, a fim de ampliar suas forças e habilidades para diagnosticar, prevenir, curar (ou causar) enfermidades. Igualmente, alguém que jamais foi reconhecido na infância ou atuou como sacaca pode querer aprender diferentes técnicas reconhecidas ou heteróclitas para se defender, curar ou mesmo agredir, sem depender dos sacacas e outros especialistas. Estes aprendizados tardios remetem à suspeita de feitiçaria, por oposição ao "dom de nascença".

Nos contextos de disputas acirradas, qualquer ausência temporária das aldeias

\footnotetext{
${ }^{26}$ A noção de cosmopolítica ou política cósmica, aqui empregada, foi inicialmente proposta pela filósofos Isabelle Stengers e Bruno Latour e explorada com grande rendimento pela etnologia ameríndia nas últimas décadas (e.g. Sztutman, 2005; Lima, 2012). Objetiva caracterizar o pensamento e a ação política a partir de modos específicos de integração entre agentes humanos e não-humanos em um mundo culturalmente compartilhado, ou um regime sociopolítico e cosmológico, fundado em princípios ontológicos específicos. "Os índios não separam humanos de não humanos; não separam natureza e cultura; conferem intencionalidade aos animais; não diferenciam os humanos e os não humanos; consideram os animais como pessoas morais e sociais autônomas, como sujeitos sociais" (Lima, 2012: 615).
} 
ou comunidades, faz com que pessoas do outro lado levantem suspeitas e acusações de que seus inimigos estão percorrendo lugares distantes com o objetivo de lhes fazer algum mal. Mas para além dos "boatos e acontecidos", não é improvável que duas partes busquem nas cidades próximas, o apoio de um mesmo pajé, sem saber que seus inimigos estão se amparando no mesmo aliado. Caso este possível trabalho duplo seja revelado, ambas as partes irão acusá-lo de querer alimentar as disputas com o intuito de cultivar a todos como clientes e obter ganhos materiais de parte a parte. Isso tenderá a fazer com que as suspeitas sobre a origem do conflito se voltem contra o próprio pajé.

Na prática, o diagnóstico é mais complexo, uma vez que as agressões virtuais podem também ser provocadas pelos encantados. O mau-olhado, ataque, roubo, assombro ou flechada, provocados pelos "bichos do fundo", podem acontecer "por agrado": "às vezes os bichos se agradam da pessoa, judiam, porque querem levar para o fundo". Ou então devido ao desrespeito a regras básicas de boa convivência estabelecidas pelos "donos ou mães da paragem" onde habitam.

Pessoas com o corpo excessivamente aberto, como as crianças ou os sacacas, são mais suscetíveis a estas agressões. Já dito, o sangue tem "cheiro forte" e funciona como um atrativo para os encantados. Por isso, uma mulher menstruada é alguém que está com o corpo temporariamente aberto e suscetível a atrair um ataque dos "bichos do fundo". Esta é a razão da necessidade de que respeitem os resguardos menstruais. Quando se encontram nestes "tempos", as mulheres devem evitar circular sobre áreas nas quais "a mãe ou o dono para", como as cabeceiras dos igarapés ou as beiras dos rios. Estes cuidados devem ser redobrados em horários de reponto do dia e da noite, quando, por rotina, os encantados sobem aos montes à superfície. Mesmo dentro de casa, as mulheres em seus tempos e suas famílias podem não estar seguras. Para evitar a aproximação dos bichos do fundo, um método comumente utilizado são os banhos e defumações com "plantas fortes", as mesmas que podem ser usadas para as defumações com cigarro de tauari.

Um aspecto fundamental do desrespeito aos resguardos menstruais é que os bichos do fundo não atacam necessariamente a mulher, mas sim um terceiro. Geralmente explicam este processo a partir de um exemplo básico. "Se uma mulher menstruada 
passa sobre um igarapé, isto faz com que seus donos fiquem bravos ou atraídos; podendo querer roubar a sombra não dela, mas do próximo que passar". Isso leva a que os resguardos menstruais sejam um tema e um problema não apenas para a mulher menstruada, mas sim para o coletivo; todos aqueles que vivem juntos em uma paragem ou circulam pelos mesmos lugares. Também nesta dimensão - e retomando o trocadiIho de Claude Lévi-Strauss - podemos dizer que "a filosofia indígena resguarda a sua originalidade" (2008 [1968]: 455) 27 .

Os casos graves de roubo da sombra apenas podem ser revertidos pela ação dos pajés que, em suas práticas rituais, tentam apaziguar, negociar, convencer ou afastar os encantados para que a sombra volte para o corpo do enfermo. O insucesso nestas tentativas tem como desfecho a captura definitiva da sombra. Logo, a pessoa roubada é alguém que "morreu como gente e passou a pertencer aos encantados". A diferença básica entre a viagem ao fundo pelo sacaca, vestido em uma capa de cobra grande, e a viagem ao fundo por ataque de bicho, é que os sacacas circulam entre a terra e o fundo por vontade e consciência próprias, ao passo em que a pessoa que tem a sombra roubada viaja ao fundo à revelia.

Em minha pesquisa, o problema do "tornar-se panema" - incapacidade temporária que aflige caçadores, pescadores e seus artefatos - comum na Amazônia indígena e cabocla (e nos estudos americanistas ${ }^{28}$ ) era tema relevante de discursos, e de práticas rotineiras. Ficar panema é o efeito do contra-ataque dos encantados, notadamente, as mães ou donos de animais, peixes e lugares atacados. A predação excessiva e continuada em um mesmo local, ou o descaso para com as presas e suas paragens, faz com que as mães ou donos ajam em represália. Homens ficam panema também por descuido das mulheres no tratamento das espécies abatidas, ou por mexer em seus artefatos. Para espantar a panema, homens e casais usam banhos e defumações. Em casos mais dramáticos, aqueles que são acometidos pela panema só ficam bons nas mãos de um sacaca, introduzindo a vítima no périplo dos enfeitiçados.

\footnotetext{
${ }^{27}$ Lévi-Strauss desdobrou extensamente o tema na A origem dos modos à mesa. Mitológicas 3 (2008 [1968]). Para uma descrição de um análogo, focada nos Wajãpi, povo Tupi, cf. Gallois (1988)

${ }^{28} \mathrm{O}$ complexo da penema é mais comum entre indígenas do que supunham autores como Galvão (1951, 1955); Wagley (1957 [1953]) ou Da Matta, (1967), que debateram o tema como uma prática tipicamente tupi. Para processos Tupi análogos aos praticados no Arapiunss e Baixo Tapajós, leia, por exemplo, Gallois (1988) sobre os Wajãpi (Amapá), ou Garcia (2010) sobre os Awá-Guajá (Maranhão).
} 
Em linhas gerais, portanto, as agressões por encantados (flechada de bicho e panemice) e as agressões de origem humana podem ser compreendidas como um único complexo em dois eixos (i) o vertical, cosmológico, (fundo/terra), que envolvem encantados e pessoas; e (ii) no horizontal, geográfico e sociológico, em que diferentes pessoas e gentes se relacionam entre $\mathrm{si}^{29}$.

\section{Sacaca e o encantado; o inimigo e o bicho de terra}

Os principais conhecedores destacaram que vestir e desvestir capas corporais, tipo cobra grande, habilidade de sacaca e encantado, contrasta e não se confunde com processos de metamorfose corporal, reversíveis ou não, em que uma pessoa "se gera em um bicho de terra".

A categoria "se gerar" ou "engerar" - tema chave em etnografias contemporâneas na regiã ${ }^{30}$ - é comumente utilizada para denotar qualquer processo de transformação em que "uma coisa se gera para outra". "Pequenos peixes se geram em sapos; assim como os bichos do coco do curuá se geram em borboletas". O medo do caçador solitário pode gerar o "remanso" ou "remorso", isto é, o sinal da presença de um bicho perigoso, mesmo quando diante de bichos inofensivos como as pacas ou os urubus. Do mesmo modo, e como já descrito, uma agressão de feitiçaria remete ao processo em que algum agente patológico é gerado no corpo da pessoa agredida.

Apesar de ter ouvido diversas vezes que o "encantado ou o sacaca se gera em cobra grande", não raro curadores e outros entendidos contrastavam os processos de "se gerar" e "se encantar", para marcar a diferença entre transformações de ordem distinta. Nesta chave, o "se gerar" é aplicado de modo restrito a casos em que pecadores e outros tipos se metamorfoseiam em bichos de terra: onças, porcos ou juruparis. Trata-se de uma penitência que pode decorrer de pecados mortais, como o assassinato ou o incesto ${ }^{31}$. Por exemplo, o caso de um velho que habitava sozinho uma das cabeceiras de um lago,

\footnotetext{
${ }^{29}$ Para uma introdução, à exploração etnográfica nos eixos cosmológico e sociológico, como aqui sugerido, cf. Lévi-Strauss (2004 [1964]).

${ }^{30} \mathrm{Cf}$. João Valentin Wawziniak $(2008,2012)$, Emilie Stoll (2015).

${ }^{31} \mathrm{O}$ contraste que os povos do Arapiuns estabelecem entre os processos de "vestir uma capa", que envolvem as transformações corporais vividas pelos pajés-sacacas, e os processos de "se gerar", associados ao cumprimento de uma penitência, foi também notado por Candace Slater (1994) entre as populações de Parintins (AM), e por Mark Harris (2000) entre as populações do baixo Trombetas.
} 
à distância de sua esposa, filhos e outros parentes próximos. O rumor era que "o velho solitário se gerava para porco", porque teria "andado pelo mato com a própria mãe".

Uma outra causa recorrente é a avareza, a recusa a compartilhar pedaços de carne ou parte dos peixes pescados ("putáuas") com os vizinhos. O isolamento continuado do convívio social nos centros de mata é também associado a estes processos. Por exemplo, as histórias sobre uma velha que morava só em um centro de mata e não saía dali para nada. Contam que ela se gerava para onça e saía para caçar seus alimentos. Um dia seu marido resolveu visitá-la; quando chegou perto da casa, uma onça partiu para cima dele. Logo, no entanto, ele percebeu que o bicho tinha um dente de ouro e concluiu que se tratava de sua mulher, o que o fez desistir de atirar no bicho e de retornar ao lugar. Desde então a velha passou a ser visitada apenas por uma amiga. Contam que um dia, esta amiga sumiu e que, tempos depois, encontraram sua ossada em meio a uma capoeira alta. Uma vez que apenas as onças levam o corpo para comer no "feio das matas", a única explicação plausível para este desfecho trágico foi que a velha teria se gerado para onça e comido sua amiga.

Processos de mesmo tipo são a base da geração de bichos perigosos de mata como os juruparis, que, entre eles, são descritos como bichos grandes com uma capa grossa de inseto, que tem uma grande boca no peito ou no coração. Os velhos dizem que os antigos contavam que os juruparis são bichos que se geraram de tuxauas velhos. Relatam que, de primeiro, um tuxaua velho era morto a pauladas pelos mais novos que queriam tomar seu lugar. Para evitar ser morto, o tuxaua velho saía sozinho pelas matas e por lá ia se tornando um bicho perigoso, inclinado a comer as pessoas. O gerar-se em jurupari, pelo qual passa um tuxaua velho, remete, neste sentido, aos processos nos quais as gerações mais novas passam a querer tomar para si as posições de liderança ocupadas pelos mais velhos 32 .

Embora associem estas disputas entre jovens e velhos chefes ao passado longínquo, é possível observar eventos semelhantes no presente. Em uma das aldeias, acompanhei momentos de uma tensa e longa disputa territorial entre um jovem casal,

\footnotetext{
${ }^{32} \mathrm{Na}$ mesma região, Wawziniak (2012) apresentou descrições semelhantes acerca da formação dos juruparis. Slater (1994) sugere que outros "bichos de mata", como os mapinguaris e as matintas-pereiras podem ser observadas no mesmo eixo.
} 
que aos poucos ganhava destaque em posições de liderança, e um outro formado por dois velhos solitários, que em muito contribuíram para a formação da comunidade no passado. Em nossos diálogos, este jovem casal, além de reclamar da longevidade de seus antagonistas e os acusarem de feitiçaria, afirmavam, categoricamente, que eles se geravam para porcos durante a noite.

A feitiçaria também pode ser a causa destas metamorfoses. Gerar-se em bicho de terra é o destino de quem aprende orações más por intermédio de livros, como o livro de São Cipriano. Mais de um velho explicou-me que os juruparis se geram não apenas de tuxauas velhos, mas também de feiticeiros. Com efeito, dizer algo como "o jurupari está seguindo alguém", é levantar suspeitas de feitiçaria.

Estas metamorfoses corporais em "bichos de terra", associadas a relações antissociais e pecados mortais, não se confundem com a circulação voluntária entre a terra e o fundo. Explicam que o ato de vestir uma capa corporal e viajar pelo cosmos pertence ao fundo, enquanto que o de se gerar, que envolve apenas o eixo terrestre, ocorre por intermédio do satanás ou do inimigo. Nas transformações que ocorrem por intermédio do inimigo é o próprio corpo que se transforma em bicho, o que não se confunde com a habilidade do espírito de vestir uma capa corporal diferente daquela que recebeu em seu nascimento.

Neste sentido, o sacaca é um cristão em uma outra forma corporal, e não alguém que se transforma no próprio bicho e que "passou para o lado do inimigo". Enquanto o sacaca que "adquire uma outra formatura" mantém sua posição de sujeito sob uma outra vestimenta corporal, a pessoa que "se gera" é capturada pela perspectiva do bicho de terra e perde a capacidade de enxergar gentes e parentes nos mesmos referentes corporais. Se é bicho, é perigoso, pode se voltar contra os próprios humanos. O caso da mulher que se gerou em onça e comeu sua única amiga, ou dos antigos tuxauas velhos que se geravam em juruparis, sedentos por comer gente, evidenciam o grande perigo associado a estes processos 33 .

\footnotetext{
${ }^{33}$ Estas concepções nativas sobre estes processos de transformação corporal parecem operar como uma variante daquilo que Eduardo Viveiros de Castro $(2002,2004)$ sintetizou como a filosofia ontológica do perspectivismo ameríndio, amplamente disseminadas entre as povos indígenas das terras baixas da América do Sul.
} 
É preciso destacar, no entanto, que assim como o contraste conceitual que estabelecem entre o pajé-sacaca e o feiticeiro, a distinção que estabelecem entre os processos de "se gerar" e de "vestir uma capa" não é estanque nem definitiva, mas posicional. Primeiro, porque a noção de "se gerar" serve para designar processos gerais de transformação que, a depender do contexto e do enunciador, podem ser utilizadas como um sinônimo do "vestir uma capa". Segundo, porque dizer que "o curador se gera" pode ser um modo de associar um pajé inimigo e seus aliados ao polo da feitiçaria. O sacaca aliado "veste uma capa", enquanto o inimigo "se gera para bicho".

Afirmar que o mundo dos sacacas e encantados, de um modo geral, "têm parte com o inimigo ou o inferno" é também um modo de destacar o próprio pertencimento "à parte de deus e do bem, sem suspeitas ou enganação". Nesta chave, o encante é como o "inferno, destino dos pecadores, morada do inimigo". Embora esta linha de raciocínio seja comum entre pessoas e famílias vinculadas a cultos protestantes, também católicos adotaram discursos semelhantes. Mas observe que apegar-se ao mundo de deus, à bíblia e à religião não significa que a pessoa passa a acreditar que encantados não existem, ou que os sacacas não têm poder. É porque "as forças do mundo, abaixo de deus", as pessoas comuns e os encantados, são "para o bem ou para o mal", que "deus é o caminho". Portanto, apegar-se a deus é também uma estratégia cosmopolítica e diplomática, um esforço para manter o mundo pacificado, à distância da ambivalência perigosa de gentes e bichos, na terra e no fundo.

\section{O sacaca, o "ritual da fogueira" e a "seita de feiticeiros"}

Desde a virada do milênio, o movimento indígena regional (re)inventou em seus encontros, a tradição de fazer rituais em volta da fogueira, em que cantam, dançam e discursam, de mãos dadas, comumente junto a figuras destacadas de fora, como as autoridades. Nestes momentos, é comum celebrarem os grandes pajés sacacas, Merandolino e Laurelino; convidando a eles e outros encantados ao centro da roda, para ao final agradecerem e pedirem seu retorno às matas e rios, sua a saída do espaço da aldeia.

Por óbvio, esta tradição inventada recentemente é mobilizada em ocasiões politicamente estratégicas, direcionadas a agentes que podem influir sobre seus processos 
formais de acesso a direitos. O observador externo desatento (ou mal-intencionado), pode bem considerar que estas elaborações secundárias da "cultura" não são nada além de objetos postiços, inventados arbitrariamente para fins utilitários. Contudo, é preciso considerar, conforme sintetizou Marshall Sahlins, que "qualquer que seja a validade histórica de tais racionalizações, elas são funcionalmente consistentes com a ordem histórica imanente" (1997: 136). Significa que: "a defesa da tradição implica alguma consciência; a consciência da tradição implica alguma invenção; a invenção da tradição implica alguma tradição" (id.).

A vitalidade desta "tradição implicada" se manifesta com clareza em um efeito negativo, aparentemente imprevisto, que estes rituais em volta da fogueira provocam em parte dos locais, indígenas e caboclos, que volta e meia participam ou observam a distância. Para estes críticos locais, o "ritual da fogueira" é problemático, não porque evoca temas ou figuras que não fazem sentido, mas porque cria um tipo de "arrumação" que pode gerar consequências perigosas já previsíveis para "quem conhece a cultura".

Primeiro, porque chama para o centro da comunidade, encantados e sacacas poderosos como Merandolino e Laurelino, que deveriam ser mantidos a certa distância do espaço das casas, onde as pessoas é que são os donos. Segundo porque cultuar pajés sacacas como aos santos cristãos, em volta da fogueira, estaria mais para o que muitos definiram como uma "seita de feiticeiros" ou "enganadores".

\section{Considerações finais}

A pajelança e os regimes sociopolíticos e cosmológicos subjacentes - aqui esboçados para a zona de confluência entre os rios Arapiuns, Tapajós e Amazonas - ressoam a muitas outras beiradas de rio e centros de mata, habitados por populações tradicionais "caboclas" ou por povos indígenas ditos puros ou autênticos. Mas apesar do contínuo indígena-caboclo ser evidente, a antropologia rural adverte que a "cultura cabocla" também se nutre de expressões culturais portuguesas e africanas; além de ser compartiIhada, em maior ou menor medida, por segmentos nacionais de diversas origens. Em outras palavras, estes estudos reiteram que a "cultura cabocla" é também - em linhas gerais - a cultura do "mucambeiro" (quilombola) ou do "arigó" (cearense) - conforme os termos utilizados por meus interlocutores. Contudo, mesmo sendo sincrética e aberta a 
influências exógenas as mais diversas, a cultura cabocla continua sendo marcadamente indígena. Como entender e situar estas evidências aparentemente contraditórias?

Nos anos 2000, o tema foi objeto de um interessante debate proposto por João Valentim Wawziniak (2008). O autor bem observou que as "sociedades caboclas" do Baixo Tapajós e Arapiuns vivem em um "universo cosmológico" que bem pode ser sintetizado na fórmula proposta por Peter Rivière (1995) para os indígenas na Amazônia. Trata-se de um "mundo altamente transformacional" onde "as aparências corporais enganam". Afinal, uma onça ou um porco meio estranho pode bem ser uma pessoa engerada, um pecador. Ou então, um encantado, o dono ou mãe do animal, circulando em terra entre suas crias. Nunca se sabe.

É por isso que este modo de equacionar metamorfoses corporais e mudanças de perspectiva - em um fundo cultural compartilhado por humanos e não-humanos - pode ser entendido como uma variante transformacional do modelo relacional que Tânia Stolze Lima e Eduardo Viveiros de Castro chamaram de "perspectivismo ameríndio". O corpo é "o lócus de expressão das diferenças de perspectiva"; "as mudanças corporais são causa e instrumento de mudanças nas relações sociais" (Viveiros de Castro, 2002: 63).

Para Wawziniak, as semelhanças são evidentes porque "as sociedades e culturas caboclas da Amazônia são informadas ou se nutrem das tradições indígenas". Mas por outro lado, o "perspectivismo ameríndio" não se restringe ao pensamento indígena. Enquanto "operação elementar do espírito humano", argumentou o autor, o animismo está em toda parte: entre indígenas e caboclos, como nos petshops de bairros nobres ou no "jogo do bicho" carioca. Mas apesar de interessante, esta generalização descontrolada acaba por deslocar ou esvaziar o debate sobre as especificidades do mundo compartiIhado por indígenas e caboclos.

Em homenagem póstuma a Wawziniak, Raymundo Maués (2012), célebre estudioso da pajelança cabocla, reiterou esta linha de análise, enfatizando as descontinuidades entre indígenas e camponeses tradicionais. Existem "índios, não índios, mas também populações que reivindicam seu reconhecimento étnico"; todas são "populações rurais da Amazônia" (2012: 34). Lembrou também que identificar semelhanças entre povos indígenas e camponeses tradicionais não é propriamente novo. Afinal, tanto os cronistas e 
folcloristas, como os primeiros etnógrafos modernos (Wagley \& Galvão) destacaram a forte influência indígena, notadamente Tupi, na cultura cabocla. A antropologia rural na Amazônia deslocou seu foco sobretudo a partir dos anos 1970, quando ele e outros autores passaram a enfatizar a "mescla entre concepções e práticas católicas e o universo da pajelança" (id.:37).

É duplo o objetivo da antropologia rural da pajelança proposta por Maués, em um viés estruturalista. Por um lado, evidenciar como as chamadas "cosmologias caboclas" operam "uma bricolagem de múltiplas concepções" (id.:38); "um campo de variações em torno de temas comuns e universais do espírito humano" (id.:50). Por outro, evidenciar que Amazônia rural não é redutível aos "índios de qualquer origem", pois que existem também descendentes de africanos, nordestinos ou portugueses. Por isso, seria um equívoco reduzir a complexidade das "cosmologias caboclas" às "sociedades indígenas". Mas ainda assim, mesmo que se atente para a presença de pessoas e comunidades de origens diversas, continua a ser evidente que as tradições indígenas estão profundamente implicadas nos regimes sociopolíticos e cosmológicos que operam entre os camponeses tradicionais do rio Arapiuns e Baixo Tapajós. Assim como é destacada a presença de fenótipos e narrativas genealógicas que remetem a descendentes de índios, puros e misturados.

É possível que existam diferenças demográficas e culturais profundas entre a Costa do Salgado e o Baixo Tapajós, mas este não é o caso. O objetivo da antropologia rural de Maués é dar sentido às expressões da cultura cabocla em ambas as regiões. Em minha pesquisa de campo, não recolhi referências relevantes ou notáveis sobre figuras como o Rei Sebastião, por exemplo. Para o observado e esboçado, não faz sentido dizer que temas cosmológicos chave como o "roubo da sombra" e a "sedução do boto" ressoam a narrativas indígenas do mesmo modo como às lendas europeias de encantamento de príncipes e princesas. Ademais, distinções tipológicas que estabelecem um divisor radical entre indígenas e caboclos não contribui para maior inteligibilidade sobre este contexto etnográfico.

Maués e outros (e.g. Boyer, 1999) argumentam que o xamanismo indígena e a pajelança cabocla são diferentes porque o primeiro remete à viagem cósmica e o segundo 
à possessão. $O$ trabalho dos pajés sacacas no Arapiuns e Baixo Tapajós não corrobora qualquer distinção neste sentido. Enquanto um encantado usa o corpo do sacaca como capa, em um ritual controlado com tauari, o sacaca usa o corpo de uma cobra grande para viajar até o fundo. No xamanismo indígena amazônico, como bem demonstrou Jean-Pierre Chaumeil (1998 [1983]) a partir do caso Yagua, não existe contradição, mas complementaridade entre possessão e viagem cósmica. Embora feitiçaria exista por "todas as partes do mundo", o sacaca as interpreta a partir de um ponto de vista situado. Dizer que animismo ou perspectivismo ameríndio existe em todas as partes do mundo, enquanto manifestação do espírito humano, desloca a questão sobre as especificidades da história indígena no rio Amazonas e adjacências.

A esta linha da antropologia rural, é como se enfatizar as continuidades entre indígenas e caboclos equivalesse a um recuo à perspectiva adotada por folcloristas e cronistas de séculos atrás, reduzindo a complexidade da mestiçagem a apenas um de seus componentes. Por exemplo, o caso dos sacacas ou famílias de enfermos sem diagnóstico e cura, que circulam pelas cidades em busca de novos especialistas - de pais de santo a cirurgiões - trazendo de volta novidades. Não se trata de perda cultural, tampouco de mescla equilibrada de elementos culturais de mesmo tipo. Com efeito, o sincretismo da pajelança cabocla no Arapiuns não é distante da pajelança dos Shuar (Amazônia equatoriana), que combinam às práticas tradicionais, "referências emprestadas do cristianismo, do budismo, da yoga, da medicina chinesa, dos conceitos New Age ou também os rituais Sun Dance norte-americanos" (Mader, 1999: 8 ap. Chaumeil, 2000:152). Apesar de combinar uma grande variedade de elementos exógenos, tanto a pajelança shuar como a praticada no Arapiuns oferecem o que Chaumeil chamou de “imagem compósita” (2000:152) construída a partir da perspectiva indígena.

O legado indígena (Tupi) não é exatamente uma "parte [importante ou acessória] da cultura do caboclo", mas um conjunto articulado de princípios e modos de mesclar e incorporar influências externas. Neste sentido, acompanho a crítica do etnólogo dos Yagua, de que nas últimas décadas, noções culturalistas de sincretismo e mestiçagem passaram operar como conceitos passe-partout (2000:162). Esta expressão francesa, traduzível por conceitos como "chave-mestra" ou "código de acesso", evoca ideias aplicadas a tudo, em toda parte, do mesmo modo. O sincretismo pode ser entendido como 
modo de relação indígena, porque opera como estratégia de controle de poderes "de fora", que remete diretamente ao tema da abertura nas filosofias ameríndias. Não se trata de obliterar a importância da "mestiçagem", mas de reconhecer suas especificidades.

Afinal, como esboçado, se muitas pessoas, pelo Arapiuns e Tapajós, se apegam a deus e recusam o mundo da pajelança, não é porque entendem que seus conceitos e práticas não fazem sentido. Pelo contrário, apegar-se ao caminho da bondade inequívoca de deus é mais uma tentativa de apaziguar ou afastar a ambivalência e o perigo dos sacacas e encantados; que, em última instância, é o perigo e a ambivalência de qualquer ser humano entre a terra e o fundo.

Não se trata de reduzir a complexidade da Amazônia cabocla, formada pela mistura entre diversos tipos de gente (indígenas, brancos, negros...), arbitrariamente em favor de um de seus componentes. Tampouco de negar ou tentar controlar a proliferação de híbridos em nome de uma cultura inventada como se fosse pura. Talvez uma das maiores injustiças cometidas contra os povos indígenas amazônicos - para além do genocídio, esbulho e escravização - seja a tendência, alimentada também por nossas ciências, a reduzi-los a isolados de "cultura autêntica". Talvez os folcloristas e cronistas do século XIX e começo do XX, tenham sido a seu modo e em seu contexto, mais sensíveis a este ponto. Afinal, ao afirmar que os "projetos de civilização" faliam na Amazônia, estavam dizendo que os índios é que estavam civilizando os diversos tipos de gente que ia entrando pelos rios.

\section{Referências}

Almeida, Mauro. 2002. The Politics of Amazonian Conservation: The Struggles of Rubber Tappers. The Journal of Latin American Anthropology, (1), p. 170-219, 2002.

Amoroso, Marta. O nascimento da aldeia mura: sentidos e modos de habitar a beira. Amoroso, M.; Santos, G. M. (Org.) Paisagens Ameríndias: lugares, circuitos e modos de vida na Amazônia. São Paulo: Terceiro Nome, p. 93-114, 2013. Barbosa Rodrigues, J. Exploração e estudo do Valle do Tapajós. Rio de Janeiro: Typografia Nacional, 1875.

Bessa Freire, José Ribamar. Rio babel: a história das línguas na Amazônia. Rio de Janeiro: Atlântica, 2004.

Bolaños, Omaira "Reconstructing Indigenous Ethnicities The Arapium and Jaraqui Peoples of the Lower Amazon, Brazil”. Latin American Research Review, v. 45, n.3, p. 63-86, 
2010.

Boyer, Véronique. "O Pajé e o Caboclo: de homem a entidade". In: Mana, v. 5, n. 1, p. 29-56, 1999.

Carneiro da Cunha, Manuela. 1998. "Pontos de vista sobre a floresta amazônica: xamanismo e tradução". Mana, v.4, n.1, p. 7-22, 1998.

Chaumeil, Jean-Pierre. Ver, Saber, Poder. El chamanismo de los Yagua de la Amazonía Peruana. Lima: IFEA, CAAAP, CAEA-CONICET, 1998 [1983].

Cravalho, Mark. "Shameless Creatures: An Ethnozoology of the Amazon River Dolphin". Ethnology, v. 38, n. 1, p. 47-58, 1999.

Da Matta, Roberto. “La 'panema' en essai d'analyse structurale”. In: L'Homme, t. 7, n. 3, p. 5-24, 1967.

Daniel, João. Thesouro Descoberto no rio Amazonas: notícia geral dos índios seus naturaes, e de algumas nações em particular: da sua fé, vida, costumes, e das cousas mais notáveis da sua rusticidade. In: Revista Trimensal do Instituto Histórico Geographico e Ethnographico do Brasil, tomo III. Rio de Janeiro.

De Lima, Leandro Mahalem. No Arapiuns, entre verdadeiros e - ranas: sobre os espaços, as lógicas, as organizações e os movimentos do político. 2015. Tese (Doutorado em Antropologia Social) - Faculdade de Filosofia, Letras e Ciências Humanas, Universidade de São Paulo, São Paulo, 2015.

De Lima, Leandro Mahalem. Rios Vermelhos: perspectivas e posições de sujeito em torno da noção de 'cabano' na Amazônia em meados de 1835. 2008. Dissertação (Mestrado em Antropologia Social) - Faculdade de Filosofia, Letras e Ciências Humanas, Universidade de São Paulo, São Paulo, 2008.

De Lima, Leandro Mahalem. Terras Indígenas e outros territórios tradicionais se complementam? Ricardo, B.; Ricardo F. Povos indígenas no Brasil 2011/2016. São Paulo: Instituto Socioambiental, 2017.

Fausto, Carlos. Donos demais: maestria e domínio na Amazônia. Mana,v.14, n.2, Rio de Janeiro, p. 329-366, 2008.

Gallois, Dominique. O Movimento na Cosmologia Waiãpi: criação, expansão e transformação do universo. Tese (Doutorado em Antropologia), FFLCH-USP, São Paulo, 1988.

Galvão, Eduardo. Santos e visagens: um estudo da vida religiosa de Itá, Baixo Amazonas. São Paulo, Nacional, 1955.

Garcia, Uirá Felippe. Karawara: a caça e o mundo dos Awá-Guajá. 2010, 456 p. Tese (Dourorado em Antropologia) - FFLCH-USP, São Paulo.

Gomes, Denise. Politics and Ritual in Large Villages in Santarém, Lower Amazon, Brazil. Cambridge Archaeological Journal, p. 1-19, 2016.

Gow, Peter. "River People: Shamanism and History in Western Amazonia". In: Thomas, Nicholas \& Humphrey, Caroline (Eds.). Shamanism, History, and the State. Ann Arbor: The University of Michigan Press, 1994, p: 90-113.

Grenand, François ; Grenand, Pierre. "L'identité insaisissable: Les caboclos amazoni- 
ens". Études rurales: Identité et sociétés nomades. Symboles, normes et transformations, v.. 120, n. oct.-dec., EHESS, Paris, p. 17-39, 1990.

Harris, Mark (Org.). Some other Amazonians: perspectives on modern Amazonia. London: Institute for the Study of the Americas, p. 12-36, 2004.

Harris, Mark. "Seeing through the smoke: notes on Amazonian caboclo shamanism". Acts of the Conference: Image, Performance and Representation in American Shamanic Societies, St. Andrews, 2003.

Harris, Mark. Life on the Amazon: the anthropology of a Brazilian peasant village. Oxford University Press, 2000.

Harris, Mark. Rebellion on the Amazon: the Cabanagem, race, and popular culture in the North of Brazil, (1798-1840) University Press, Cambridge, 2010.

Hugh-Jones, Stephen. 1994. "Shamans, Prophets, Priests and Pastors". In: Thomas, Nicholas \& Humphrey, Caroline (Eds.). Shamanism, History, and the State. Ann Arbor: The University of Michigan Press, 1994, p: 32-75.

Ioris, Edviges Marta. "Sombras, pessoas e xamanismo". IX Reunião de Antropologia do Mercosul, RAM, GT69, Curitiba, 2011.

Lévi-Strauss, Claude. A origem dos modos à mesa. Mitológicas 3. São Paulo: Cosac \& Naify, 2006 [1968].

Lévi-Strauss. Claude. O cru e o cozido. Mitológicas 1. São Paulo: Cosac \& Naify, 2004 [1964].

Lima, Deborah M. O Homem de Branco e o Boto: O Encontro Colonial em Narrativas de Encantamento e Transformação (Médio Rio Solimões, Amazonas). Teoria \& Sociedade (UFMG), v. especial, p. 173-201, 2014.

Lima, Deborah M. The social category caboclo: history, social organization, identity and outsider's social classification of the rural population of an amazonian region, King's College, Cambridge, 1992.

Maizza, Fabiana. 2012. Cosmografia de um mundo perigoso. Espaço e relações de afinidade entre os Jarawara da Amazônia. Ed. Nankin, Edusp, São Paulo.

Maués, Raymundo H. \& Villacorta, Gisela M. (Org.). 2008. Pajelança e Religiões Africanas na Amazônia. Belém: Ed UFPA.

Maués, Raymundo H. 2012. "O perspectivismo indígena é somente indígena? Cosmologia, religião, medicina e populações rurais". Mediações - Revista de Ciências Sociais, v. 17, n.1 (jan/jul). Londrina: UEL/Regente. Pp. 33-62.

Maués, Raymundo H. A Ilha Encantada: Medicina e Xamanismo numa comunidade de pescadores. Tese (Doutorado em Antropologia), UnB, 1977.

Maués, Raymundo Heraldo. “Bailando com o Senhor': técnicas corporais de culto e louvor (o êxtase e o transe como técnicas corporais)". Revista de Antropologia USP, v. 46, n. 1, p. 09-40, 2003.

Maués, Raymundo Heraldo. "Um aspecto da diversidade cultural do caboclo amazônico: a religião". Revista de Estudos Avançados USP, v. 19 (53), São Paulo, p. 259-274, 2005. 
Maybury-Lewis, David. 'Demystifying the second conquest'. Schmink and Wood (eds) Frontier Expansion in Amazonia. Gainesville: University of Florida, p. 127-134, 1984.

Meggers, Betty. 1950. Caboclo Life in the Mouth of the Amazon. Primitive Man, v. 23, n. 23 1/2 (Jan-Abr), p. 14-28, 1950.

Moreira Neto, Carlos de Araújo. Índios da Amazônia, de maioria a minoria (1750-1850). Vozes, Petrópolis, 1988.

Moura de Figueredo, Aldrin. A Cidade dos Encantados: pajelanças, feitiçarias e religiões afro-brasileiras na Amazônia. Dissertação de Mestrado (História Social), IFCH-Unicamp, Campinas, 1996.

Nimuendajú, Curt.1946. The Mawé and the Arapium. Steward J. (Ed.) The Handbook of South American Indians. U.S. Gov. \& Smithsonian Institution, Washington.

Nugent, Stephen. Amazonian Caboclo Society: An Essay on Invisibility and Peasant Economy. Oxford: Berg, 1993.

Parker, E. (Ed.) The Amazon Caboclo: Historical and Contemporary Perspectives. Williamsburg, College of William and Mary, 1985.

Rivière, Peter. AAE na Amazônia. Revista de Antropologia, v. 38, n. 1, p. 191-203, 18 jun. 1995.

Sahlins, Marshall. O "pessimismo sentimental" e a experiência etnográfica: por que a cultura não é um "objeto" em via de extinção (parte II). Mana, Rio de Janeiro, v. 3, n. 2, p. 103-150, 1997.

Sauma, Julia. The Deep and the Erepecuru: Tracing Transgressions in an Amazonian Quilombola Territory. Tese (Doutorado em Antropogia Social). London, University College London, 2013

Seeger, Anthony; Da Matta, Roberto; Viveiros de Castro, Eduardo. "A construção da pessoa nas sociedades indígenas brasileiras“. Boletim do Museu Nacional, n. 32, p. 2-19, 1979.

Slater, Candace. 1994. Dance of the Dolphin: transformation and disenchantment in the Amazon imagination. Chicago: The University of Chicago Press, 1994.

Stenbrog, Pál; Rydén, Stig. In the Pursuit of Past Amazon: archaeological researches in the Brazilian Guyana and in the Amazon region. Museum of World Culture, Götebrog, 2004.

Stoll, Émilie, Montrer l'autre pour dire le soi, montrer le soi pour dire l'autre: la "Farce des Nègres" du bas-Tapajós (Amazonie brésilienne), Gradhiva, n. 22, p. 158-184, 2015.

Stoll, Émilie. La fabrique des entités: récits sur l'enchantement d'un riverain extraordinaire en Amazonie brésilienne. Cahiers de littérature orale, 79, 2016.

Stoll, Émilie. Rivalités riveraines : territoires, stratégies familiales et sorcellerie en Amazonie brésilienne. Tese (Doutorado em Antropologia Social, Paris, EPHE, 2014.

Stolze Lima, Tânia. Por uma cartografia do poder e da diferença nas cosmopolíticas ameríndias. Revista de Antropologia, v. 54, n. 2, 24 ago. 2012. 
Sztutman, Renato. O profeta e o principal: a ação política ameríndia e seus personagens. 2005. Tese (Doutorado em Antropologia Social) - Faculdade de Filosofia, Letras e Ciências Humanas, Universidade de São Paulo, São Paulo, 2005. doi:10.11606/T.8.2005.tde01102007-144056. Acesso em: 2018-10-11.

Vaz Filho, FLorêncio A.; Carvalho, Luciana. G. (Org.). Isso tudo é encantado. 1. ed. Santarém: UFOPA, 2013.

Vaz Filho, Florêncio. A emergência étnica do povos indígenas no baixo rio Tapajós (Amazônia). Tese (Doutorado em Antropologia Social, PPGCS-UFBA, Salvador, 2010.

Vaz Filho, FLorêncio. Pajés, benzedores, puxadores e parteiras. 1. ed. Santarem: Ufopa, 2016. v. 1. $138 \mathrm{p}$.

Vaz Filho, Florêncio; Tapajós, João A. P.; Cardoso, Luana da Silva. "Lutando por Direitos, apesar do forte preconceito". Povos indígenas no Brasil 2011/2016. São Paulo: Instituto Socioambiental, p. 443-450, 2017.

Viveiros de Castro, Eduardo. 2002. "Perspectivismo e multinaturalismo na América indígena“. In: A Inconstância da Alma Selvagem e outros ensaios. São Paulo: CosacNaify. Pp.345-401

Viveiros de Castro, Eduardo. Metafísicas Canibais: elementos para uma antropologia pós-estrutural. São Paulo: Cosac \& Naify, p. 288, 2015.

Wagley, Charles. Amazon Town: a study of man in the tropics, New York: The Macmillan Company, 1953.

Wawziniak, João V. Assombro de olhada de bicho: uma etnografia das concepções e ações em saúde entre os ribeirinhos do baixo rio Tapajós. Tese (Doutorado em Antropologia Social), UFSCar, São Carlos, 2008. 